\title{
Edible coatings maintain the phytochemicals in cold-stored 'Kinnow' mandarin (Citrus nobilis Lour x C. deliciosa Tenora) fruit
}

\author{
Arvind Kumar Baswal ${ }^{1,2^{*}}$, Harvinder Singh Dhaliwal ${ }^{1}$, Zora Singh ${ }^{3}$, Bal Vipan Chander Mahajan ${ }^{4}$, Anu Kalia ${ }^{5}$ \\ ${ }^{1}$ Department of Fruit Science, College of Horticulture and Forestry, Punjab Agricultural University, Ludhiana-141004, \\ India \\ ${ }^{2}$ Department of Horticulture, School of Agriculture, Lovely Professional University, Phagwara-144411 \\ ${ }^{3}$ Horticulture, School of Science, Edith Cowan University, Joondalup, Western Australia, 6027, Australia \\ ${ }^{4}$ Punjab Horticultural Postharvest Technology Center, Ludhiana-141004, India \\ ${ }^{5}$ Electron Microscopy and Nanoscience Laboratory, Department of Soil Science, College of Agriculture, Punjab \\ Agricultural University, Ludhiana-141004, India
}

*Corresponding author: baswal.arvind0@gmail.com

\begin{abstract}
Edible coatings usually maintain or improve the scavenger antioxidants and activities of defense-related enzymes consequently preserve the bioactive compounds. The effects of different coating treatments e.g. carboxymethylcellulose $\left(\mathrm{CMC}^{-1.0,1.5}\right.$ and $\left.2.0 \mathrm{~g} \mathrm{~L}^{-1}\right)$, chitosan $\left(0.5,1.0\right.$ and $\left.1.5 \mathrm{~g} \mathrm{~L}^{-1}\right)$, beeswax $\left(5,10\right.$ and $\left.15 \mathrm{~g} \mathrm{~L}^{-1}\right)$ and control (uncoated fruit) and cold storage period $\left(5-7^{\circ} \mathrm{C}, 90-95 \% \mathrm{RH}\right.$ for 75 days) on the levels of total phenols, total antioxidant activity, flavonoids, protein, total free amino acids and sugars (total and reducing sugars) in the juice of cold-stored 'Kinnow' mandarin fruit were assessed in 2017-18 and 2018-19. The fruit used in the experiment were harvested from the fifteen-year-old healthy trees previously grafted on rough lemon rootstock (Citrus jambhiri L.) and grown in the same block. The fruit coated with different coating treatments were stored at 5-7 $9 \mathrm{C}$ and $90-95 \% \mathrm{RH}$ for different storage periods $(0,30,45,60$ and 75 days). The levels of total phenols, flavonoids, total antioxidant activity, total and reducing sugars in the fresh juice of the cold-stored fruit were determined following each cold storage period. Amongst different coating treatments tested, CMC $\left(2.0 \mathrm{~g} \mathrm{~L}^{-1}\right)$ coating proved to be the best treatment to maintain highest levels of bioactive compounds viz., total phenols, total antioxidant activity, flavonoids and total and reducing sugars as compared to the control during cold storage. In conclusion, coating with $\mathrm{CMC}\left(2.0 \mathrm{~g} \mathrm{~L}^{-1}\right)$ was effective to extend the cold storage life and maintain the highest levels of health-promoting compounds in 'Kinnow' mandarin fruit without any symptoms of its toxicity to the fruit.
\end{abstract}

Keywords: Total antioxidant activity, flavonoids, edible coatings, mandarin. Abbreviations: CMC_Carboxymethyl cellulose.

\section{Introduction}

Citrus fruits are a bountiful source of minerals, flavonoids, phenolic acids, limonoids and adrenergic amines (Ye et al., 2011), benzoic and hydroxycinnamic acids (Sdiri et al., 2012) naringin, neohesperidin, narirutin and hesperidin (Jo et al., 2018), vitamin C and other bioactive compounds. These compounds have a positive impact on human health with proven benefits for chronic diseases like arteriosclerosis, viral activity and cancer (Habibi and Ramezanian, 2017). Improper post-harvest handling and storage conditions adversely affect the levels of various bioactive compounds and favour the development of off-flavour volatile compounds in the fruit (Rapisarda et al., 2008).

Various approaches such as modified atmospheric packaging (MAP) films (Baswal et al., 2020b), fumigation with 1methylcyclopropene (Baswal et al., 2021), post-harvest dipping with methyl jasmonate with salicylic acid (Baswal et al., 2021) have been tested to maintain the health-promoting compounds in cold-stored 'Kinnow' mandarin fruit. Earlier, some sporadic and inconclusive work has been reported only on the effects of CMC (1\%) coating on the levels of ascorbic acid, phenolics and total antioxidant activity in the short-term (30 days) cold-stored 'Kinnow' mandarin fruit (Ali et al., 2021). Amongst numerous post-harvest approaches, the application of edible coatings has been considered safe for human health and the environment (Dhall, 2013). CMC is a water-soluble derivative of cellulose that is being widely utilized in the food industry owing to its moderate permeability to water and gases, flexibility, apparent, barrier to oils and fats and great film-forming abilities (Dhall, 2013). Previously, the post-harvest application of $\mathrm{CMC}$ has been reported to extend the postharvest life of mandarins (Baswal et al., 2020a, Khorram et al., 2017; Chen et al., 2016; Arnon et al., 2015). Recently, Ali et al. (2021) reported that CMC (1\%) coating maintained significantly highest levels of ascorbic acid, phenolics and total antioxidant activity in 30 days cold-stored 'Kinnow' mandarin fruit. However, no such previous information is available on the fluctuation in the levels of flavonoids, total free amino acids 
and protein in long-term cold-stored 'Kinnow' mandarin fruit, therefore, justified to be investigated. Chitosan, a cationic, high molecular weight polysaccharide and possessing excellent film-forming and barricade properties and a non-toxic, hence is used as a raw material in the food industry (Dhall, 2013). Earlier, the post-harvest application of chitosan has been reported to enhance the storage life of different fruits such as guava (Hong et al., 2012), longan (Shi et al., 2013), mandarin (Baswal et al., 2020a; Arnon et al., 2015) and plum (Kumar et al., 2017). Recently, the post-harvest application of chitosan has been reported to maintain the highest levels of ascorbic acid in 'Kinnow' mandarin (Baswal et al., 2020a) and kumquat fruit (Hosseini et al., 2018). Whilst, the information on the dynamics of phenolics, flavonoids, total antioxidant activity, total free amino acids and protein in long-term stored 'Kinnow' mandarin fruit is lacking and warranted to be investigated.

Beeswax, a natural complex substance is comprised of alkalisoluble hydrophobic compounds. Owing to its environmental and human-health benefits, beeswax is recognized as safe chemicals (GRAS) by U.S. Food Drug and Administration (FDA) and therefore it can be used as an edible coating in the food industry (Dhall, 2013). Earlier, the post-harvest application of beeswax has been claimed to maintain the fruit quality of mandarins (Baswal et al., 2020a; Khorram et al., 2017; ParezGago et al., 2002) and mango (Eshetu et al., 2019). Additionally, the postharvest application of beeswax has been reported to maintain the highest levels of ascorbic acid in coldstored 'Kinnow' mandarin fruit (Baswal et al., 2020a), lemon (Nasrin et al., 2020) and sweet orange (Shahid and Abbasi, 2011). However, the information on the changes in the levels of phenolics, flavonoids, total antioxidant activity, protein and total free amino acids is lacking in long-term stored 'Kinnow' mandarin fruit. The health-promoting compounds are an important quality index of 'Kinnow' mandarin fruit and for human health. The present investigation was aimed to investigate the influence of different concentrations of edible coatings such as CMC, chitosan and beeswax on the levels of total phenols, total antioxidant activity, flavonoids, protein, total free amino acids and total and reducing sugars in longterm cold-stored 'Kinnow' mandarin fruit.

\section{Results}

Effects of different edible coatings and cold storage periods on the levels of total phenols in the juice

Total phenols content gradually decreased with extension in

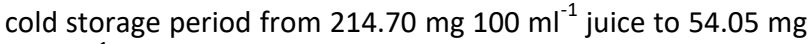
$100 \mathrm{ml}^{-1}$ juice in 30-75 days cold-stored fruit. Nevertheless, the highest mean total phenols content was recorded in fruit coated with CMC (2.0 $\mathrm{g} \mathrm{L}^{-1}$ ) (145.17 mg GAE $100 \mathrm{ml}^{-1}$ juice) contrasted to control (114.44 mg GAE $100 \mathrm{ml}^{-1}$ juice). A significant interaction was found between different coating treatments and cold storage time for total phenols content in the juice. Following 30 and 60 days of the cold storage period, fruit coated with CMC $\left(2.0 \mathrm{~g} \mathrm{~L}^{-1}\right)$ exhibited significantly higher levels of total phenols in the juice as compared with the control and all other coatings treatments. The fruit coated with CMC (1.5 $\left.\mathrm{g} \mathrm{L}^{-1}\right)$ showed a significantly higher level of total phenols in the juice as compared with the control and all other coating treatments. However, the fruit coated with chitosan $\left(1.0 \mathrm{~g} \mathrm{~L}^{-1}\right)$ resulted in significantly higher levels of total phenols in the juice of 75 days cold-stored fruit as compared to control and all other coatings treatments (Table 1).

Effects of different edible coatings and cold storage periods on the levels of total antioxidant activity in the juice

The juice of fruit coated with different edible coatings exhibited a significant decline in total antioxidant activity with an extension in the cold storage period from days 30 to 75 (39.68 \% to $11.30 \%)$. Nevertheless, the juice of the fruit coated with CMC $\left(2.0 \mathrm{~g} \mathrm{~L}^{-1}\right)$ exhibited significantly the highest mean total antioxidant activity $(30.44 \%)$ contrasted to the control $(16.75 \%)$. All the coating treatments and cold storage time had a significant interaction with total antioxidant activity in the juice. CMC $\left(2.0 \mathrm{~g} \mathrm{~L}^{-1}\right)$ resulted in significantly higher total antioxidant activity in the juice of 45,60 and 75 days of coldstored fruit respectively as compared to the control and all other coatings treatments. Whilst the fruit coated with chitosan (1.5 $\mathrm{g} \mathrm{L}^{-1}$ ) exhibited significantly higher total antioxidant activity in the juice of 30 days of cold-stored fruit as compared to the control and all other coatings treatments (Table 1).

Effects of different edible coatings and cold storage periods on the levels of flavonoids in the juice

Despite all the coating treatments, the flavonoids levels in the juice declined significantly with extension in the cold storage period from $81.81 \mathrm{mg}$ quercetin $100 \mathrm{ml}^{-1}$ juice to $39.20 \mathrm{mg}$ quercetin $100 \mathrm{ml}^{-1}$ juice (days 30-75). Although the fruit coated with $\mathrm{CMC}\left(2.0 \mathrm{~g} \mathrm{~L}^{-1}\right)$ resulted in significantly highest mean flavonoids content $\left(69.82 \mathrm{mg}\right.$ quercetin $100 \mathrm{ml}^{-1}$ juice) contrasted to control (52.13 mg quercetin $100 \mathrm{ml}^{-1}$ juice). A significant interaction was observed between different coating treatments and storage time for flavonoids content in the juice. The juice of the fruit coated with $\mathrm{CMC}\left(2.0 \mathrm{~g} \mathrm{~L}^{-1}\right)$ recorded significantly highest levels of flavonoids during all the cold storage periods as compared with the control and all other coatings treatments (Table 2 ).

Effects of different edible coatings and cold storage periods on the levels of protein content in the juice

Protein content significantly declined with extension in cold

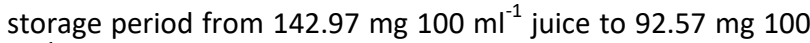
$\mathrm{ml}^{-1}$ juice in 30-75 days cold-stored fruit irrespective of the coating treatment. Nevertheless, the fruit coated with CMC $\left(2.0 \mathrm{~g} \mathrm{~L}^{-1}\right)$ resulted in the significantly highest mean protein content in the juice (131.93 mg $100 \mathrm{ml}^{-1}$ juice) contrasted to control (115.25 mg $100 \mathrm{ml}^{-1}$ juice). A significant interaction was found between different coating treatments and cold storage time for protein content in the juice. The fruit coated with $\mathrm{CMC}\left(2.0 \mathrm{~g} \mathrm{~L}^{-1}\right)$ exhibited significantly higher protein content in the juice of 30, 60 and 75 days cold-stored fruit, respectively contrasted to other coating treatments and control. Whereas, the fruit coated with chitosan $\left(1.0 \mathrm{~g} \mathrm{~L}^{-1}\right)$ manifested significantly higher protein content in the juice of 45 days of cold-stored fruit as compared with the control and all other coatings treatments (Table 3 ).

Effects of different edible coatings and cold storage periods on the levels of total free amino acids in the juice

A declining trend in the level of total free amino acids in the juice was observed with extension in cold storage period up to 
Table 1. Postharvest application of different concentrations of $\mathrm{CMC}$, chitosan and beeswax-based edible coatings and cold storage periods on the total phenols content and total antioxidant activity in the juice of 'Kinnow' fruit stored at $5-7^{\circ} \mathrm{C}$ and $90-95 \% \mathrm{RH}$

\begin{tabular}{|c|c|c|c|c|c|c|c|c|c|c|c|c|}
\hline \multicolumn{7}{|c|}{ Total phenols (mg $100 \mathrm{ml}^{-1}$ juice) } & \multicolumn{6}{|c|}{ Total antioxidant activity (\%) } \\
\hline \multicolumn{7}{|c|}{ Storage time (Days) } & \multicolumn{6}{|c|}{ Storage time (Days) } \\
\hline Treatment ( $\mathrm{T}$ ) & 0 & 30 & 45 & 60 & 75 & Mean $(T)$ & 0 & 30 & 45 & 60 & 75 & Mean $(T)$ \\
\hline $\mathrm{CMC}\left(1.0 \mathrm{~g} \mathrm{~L}^{-1}\right)$ & 129.99 & 190.35 & 149.87 & 101.66 & 65.96 & 127.56 & 26.60 & 46.79 & 26.21 & 19.71 & 12.30 & 26.32 \\
\hline $\mathrm{CMC}\left(1.5 \mathrm{~g} \mathrm{~L}^{-1}\right)$ & 129.99 & 229.48 & 183.25 & 86.25 & 57.66 & 137.32 & 26.60 & 43.05 & 34.30 & 27.64 & 11.63 & 28.65 \\
\hline $\operatorname{CMC}\left(2.0 \mathrm{~g} \mathrm{~L}^{-1}\right)$ & 129.99 & 260.87 & 168.03 & 115.03 & 51.94 & 145.17 & 26.60 & 46.00 & 37.56 & 28.19 & 13.86 & 30.44 \\
\hline Chitosan $\left(0.5 \mathrm{~g} \mathrm{~L}^{-1}\right)$ & 129.99 & 183.63 & 138.55 & 101.85 & 66.46 & 124.10 & 26.60 & 40.88 & 24.70 & 17.83 & 11.52 & 24.31 \\
\hline Chitosan $\left(1.0 \mathrm{~g} \mathrm{~L}^{-1}\right)$ & 129.99 & 245.97 & 132.67 & 96.29 & 66.96 & 134.38 & 26.60 & 46.77 & 30.32 & 21.80 & 12.61 & 27.62 \\
\hline Chitosan $\left(1.5 \mathrm{~g} \mathrm{~L}^{-1}\right)$ & 129.99 & 187.79 & 165.41 & 102.75 & 49.65 & 127.11 & 26.60 & 49.06 & 22.49 & 19.03 & 10.70 & 25.58 \\
\hline Beeswax $\left(5 \mathrm{~g} \mathrm{~L}^{-1}\right)$ & 129.99 & 189.26 & 138.04 & 90.85 & 52.86 & 120.20 & 26.60 & 28.96 & 20.90 & 13.33 & 10.65 & 20.09 \\
\hline Beeswax $\left(10 \mathrm{~g} \mathrm{~L}^{-1}\right)$ & 129.99 & 210.42 & 151.02 & 101.85 & 58.07 & 130.27 & 26.60 & 40.27 & 32.78 & 23.42 & 11.99 & 27.02 \\
\hline Beeswax $\left(15 \mathrm{~g} \mathrm{~L}^{-1}\right)$ & 129.99 & 235.80 & 123.53 & 91.70 & 36.15 & 123.43 & 26.60 & 33.18 & 21.16 & 15.54 & 9.95 & 21.29 \\
\hline Control & 129.99 & 213.43 & 120.98 & 73.04 & 34.78 & 114.44 & 26.60 & 21.84 & 16.94 & 10.64 & 7.73 & 16.75 \\
\hline Mean (ST) & 129.99 & 214.70 & 147.14 & 96.13 & 54.05 & & 26.60 & 39.68 & 26.74 & 19.71 & 11.30 & \\
\hline $\operatorname{LSD}(P \leq 0.05)$ & \multicolumn{2}{|c|}{ Treatment $(T)=7.65$} & \multicolumn{2}{|c|}{ Days $(\mathrm{ST})=5.41$} & \multicolumn{2}{|c|}{ ST $\mathrm{x} T=17.12$} & \multicolumn{3}{|c|}{ Treatment $(T)=0.53$} & ST) $=0$. & \multicolumn{2}{|c|}{$\mathrm{ST} \times \mathrm{T}=1.19$} \\
\hline
\end{tabular}

Each value indicates the pooled mean of two years of data

Table 2. Postharvest application of different concentrations of $\mathrm{CMC}$, chitosan and beeswax-based edible coatings and cold storage periods on the flavonoids content in the juice of 'Kinnow' fruit stored at $5-7^{\circ} \mathrm{C}$ and $90-95 \% \mathrm{RH}$

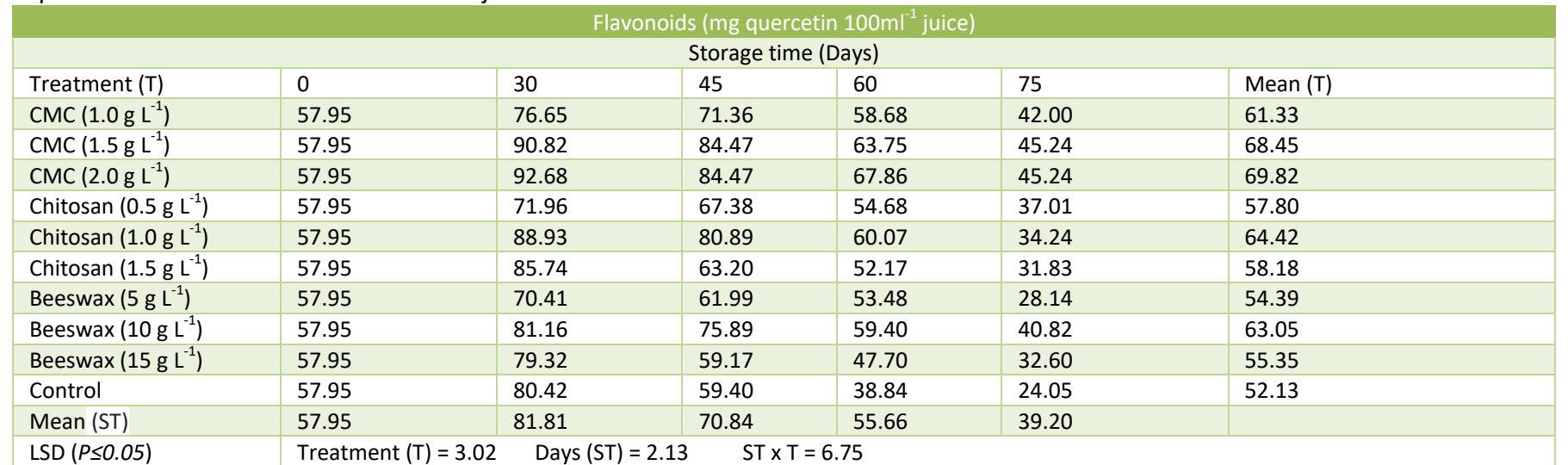

Each value indicates the pooled mean of two years of data.

Table 3. Postharvest application of different concentrations of $C M C$, chitosan and beeswax-based edible coatings and cold storage periods on protein and total free amino acids content in the juice of 'Kinnow' fruit stored at 5-7 ${ }^{\circ} \mathrm{C}$ and $90-95 \% \mathrm{RH}$.

\begin{tabular}{|c|c|c|c|c|c|c|c|c|c|c|c|c|}
\hline \multicolumn{7}{|c|}{ Protein (mg $100 \mathrm{ml}^{-1}$ juice) } & \multicolumn{6}{|c|}{ Total free amino acids (mg $100 \mathrm{ml}^{-1}$ juice) } \\
\hline \multicolumn{7}{|c|}{ Storage time (Days) } & \multicolumn{6}{|c|}{ Storage time (Days) } \\
\hline Treatment $(\mathrm{T})$ & 0 & 30 & 45 & 60 & 75 & Mean (T) & 0 & 30 & 45 & 60 & 75 & Mean (T) \\
\hline $\mathrm{CMC}\left(1.0 \mathrm{~g} \mathrm{~L}^{-1}\right)$ & 136.09 & 145.39 & 130.79 & 111.87 & 88.35 & 122.50 & 83.89 & 65.83 & 44.78 & 69.11 & 103.88 & 73.50 \\
\hline $\mathrm{CMC}\left(1.5 \mathrm{~g} \mathrm{~L}^{-1}\right)$ & 136.09 & 138.79 & 134.33 & 131.79 & 99.82 & 128.16 & 83.89 & 75.74 & 69.62 & 78.75 & 119.28 & 85.45 \\
\hline $\mathrm{CMC}\left(2.0 \mathrm{~g} \mathrm{~L}^{-1}\right)$ & 136.09 & 149.93 & 134.33 & 132.36 & 106.94 & 131.93 & 83.89 & 78.46 & 74.91 & 84.94 & 114.54 & 87.35 \\
\hline Chitosan $\left(0.5 \mathrm{~g} \mathrm{~L}^{-1}\right)$ & 136.09 & 140.99 & 119.46 & 111.93 & 98.40 & 121.37 & 83.89 & 52.59 & 39.92 & 83.78 & 97.43 & 71.52 \\
\hline Chitosan $\left(1.0 \mathrm{~g} \mathrm{~L}^{-1}\right)$ & 136.09 & 147.24 & 142.61 & 120.99 & 92.10 & 127.80 & 83.89 & 52.55 & 43.27 & 85.09 & 124.06 & 77.77 \\
\hline Chitosan $\left(1.5 \mathrm{~g} \mathrm{~L}^{-1}\right)$ & 136.09 & 141.93 & 122.78 & 116.59 & 92.37 & 121.95 & 83.89 & 55.15 & 37.44 & 83.35 & 101.37 & 72.24 \\
\hline Beeswax $\left(5 \mathrm{~g} \mathrm{~L}^{-1}\right)$ & 136.09 & 144.75 & 126.74 & 106.39 & 106.39 & 119.98 & 83.89 & 56.44 & 45.50 & 64.71 & 91.63 & 68.43 \\
\hline Beeswax $\left(10 \mathrm{~g} \mathrm{~L}^{-1}\right)$ & 136.09 & 145.67 & 136.22 & 126.87 & 85.13 & 125.99 & 83.89 & 60.23 & 48.20 & 86.41 & 102.61 & 76.27 \\
\hline Beeswax $\left(15 \mathrm{~g} \mathrm{~L}^{-1}\right)$ & 136.09 & 137.34 & 117.76 & 114.02 & 97.21 & 120.48 & 83.89 & 58.56 & 50.58 & 71.83 & 88.92 & 70.76 \\
\hline Control & 136.09 & 137.66 & 128.74 & 94.28 & 79.49 & 115.25 & 83.89 & 43.36 & 51.03 & 91.39 & 70.63 & 68.06 \\
\hline Mean (ST) & 136.09 & 142.97 & 129.37 & 116.71 & 92.57 & & 83.89 & 59.89 & 50.52 & 79.93 & 101.43 & \\
\hline $\operatorname{LSD}(P \leq 0.05)$ & \multicolumn{2}{|c|}{ Treatment $(\mathrm{T})=3.71$} & \multicolumn{2}{|c|}{ Days $(\mathrm{ST})=2.62$} & $\mathrm{ST} \times \mathrm{T}=8.30$ & & \multicolumn{2}{|c|}{ Treatment $(T)=2.23$} & \multicolumn{2}{|c|}{ Days $(\mathrm{ST})=1.58$} & \multicolumn{2}{|c|}{$\mathrm{ST} \times \mathrm{T}=4.99$} \\
\hline
\end{tabular}

Each value indicates the pooled mean of two years of data. 
Table 4. Postharvest application of different concentrations of $\mathrm{CMC}$, chitosan and beeswax-based edible coatings and cold storage periods on total and reducing sugars in the juice of 'Kinnow' fruit stored at 5-7 ${ }^{\circ} \mathrm{C}$ and $90-95 \% \mathrm{RH}$.

\begin{tabular}{|c|c|c|c|c|c|c|c|c|c|c|c|c|}
\hline \multicolumn{7}{|c|}{ Total sugars (\%) } & \multicolumn{6}{|c|}{ Reducing sugars (\%) } \\
\hline \multicolumn{7}{|c|}{ Storage interval (Days) } & \multicolumn{6}{|c|}{ Storage interval (Days) } \\
\hline Treatment $(\mathrm{T})$ & 0 & 30 & 45 & 60 & 75 & $\begin{array}{l}\text { Mean } \\
(T)\end{array}$ & 0 & 30 & 45 & 60 & 75 & $\begin{array}{l}\text { Mean } \\
\text { (T) }\end{array}$ \\
\hline $\mathrm{CMC}\left(1.5 \mathrm{~g} \mathrm{~L}^{-1}\right)$ & 5.15 & 6.56 & 6.82 & 9.13 & 8.81 & 7.50 & 2.39 & 2.68 & 3.57 & 5.05 & 4.01 & 3.54 \\
\hline $\mathrm{CMC}\left(2.0 \mathrm{~g} \mathrm{~L}^{-1}\right)$ & 5.15 & 6.82 & 8.56 & 9.23 & 9.05 & 7.76 & 2.39 & 2.92 & 4.20 & 5.20 & 4.33 & 3.81 \\
\hline Chitosan $\left(0.5 \mathrm{~g} \mathrm{~L}^{-1}\right)$ & 5.15 & 6.41 & 6.73 & 7.91 & 7.40 & 6.72 & 2.39 & 2.76 & 3.19 & 4.47 & 3.17 & 3.20 \\
\hline Chitosan $\left(1.5 \mathrm{~g} \mathrm{~L}^{-1}\right)$ & 5.15 & 6.44 & 7.20 & 8.08 & 7.27 & 6.83 & 2.39 & 2.55 & 3.00 & 4.70 & 3.67 & 3.26 \\
\hline Beeswax $\left(5 \mathrm{~g} \mathrm{~L}^{-1}\right)$ & 5.15 & 5.35 & 6.58 & 7.72 & 7.03 & 6.36 & 2.39 & 2.33 & 2.98 & 4.01 & 3.37 & 3.02 \\
\hline Beeswax $\left(10 \mathrm{~g} \mathrm{~L}^{-1}\right)$ & 5.15 & 6.23 & 7.02 & 8.54 & 8.52 & 7.09 & 2.39 & 2.56 & 3.75 & 4.82 & 3.79 & 3.46 \\
\hline Beeswax $\left(15 \mathrm{~g} \mathrm{~L}^{-1}\right)$ & 5.15 & 5.70 & 6.06 & 8.38 & 7.36 & 6.53 & 2.39 & 2.18 & 3.07 & 4.73 & 3.25 & 3.13 \\
\hline Control & 5.15 & 6.33 & 6.60 & 7.42 & 7.05 & 6.51 & 2.39 & 2.77 & 3.45 & 3.94 & 2.49 & 3.01 \\
\hline Mean (ST) & 5.15 & 6.17 & 7.10 & 8.41 & 7.99 & & 2.39 & 2.61 & 3.45 & 4.67 & 3.53 & \\
\hline
\end{tabular}

Each value indicates the pooled mean of two years.

60 days. Nevertheless, fruit coated with $\mathrm{CMC}\left(2.0 \mathrm{~g} \mathrm{~L}^{-1}\right)$ resulted in significantly highest mean total free amino acids content (87.35 mg $100 \mathrm{ml}^{-1}$ juice) contrasted to control (68.06 $\mathrm{mg} 100 \mathrm{ml}^{-1}$ juice). A significant interaction was observed between different coatings treatments and cold storage time for total free amino acids content in the juice. The fruit coated with CMC $\left(2.0 \mathrm{~g} \mathrm{~L}^{-1}\right)$ exhibited significantly higher total free amino acids content in the juice of 30 and 45 days cold-stored fruit as compared with the control and all other coatings treatments. Whilst, the fruit coated with beeswax $\left(10 \mathrm{~g} \mathrm{~L}^{-1}\right)$ showed significantly higher total free amino acids content in the juice of 60 days cold-stored fruit in contrast to all other coating treatments and control. However, the fruit coated with chitosan $\left(1.0 \mathrm{~g} \mathrm{~L}^{-1}\right)$ recorded significantly higher levels of total free amino acids in the juice as compared with the control and all other coatings treatments (Table 3 ).

\section{Effects of different edible coatings and cold storage periods on the levels of sugars (total and reducing sugars) in the juice}

Irrespective of all the coatings treatments, an elevation in the level of sugars in the juice was observed for up to 60 days of cold storage period which followed a subsequent decline till the end of the storage period. Nevertheless, the fruit coated with $\mathrm{CMC}\left(2.0 \mathrm{~g} \mathrm{~L}^{-1}\right)$ recorded significantly the highest mean total and reducing sugars in the juice $(7.76 \%$ and $3.81 \%$ respectively) as compared with the control (6.51 \% and 3.01 $\%$ respectively) and all other coating treatments. Following all the cold storage periods the fruit coated with $\mathrm{CMC}\left(2.0 \mathrm{~g} \mathrm{~L}^{-1}\right)$ exhibited a significantly higher percentage of the total and reducing sugars in the juice as compared with the control and all the coating treatments (Table 4).

\section{Discussion}

An upsurge in the level of phenolic compounds may be attributed to the reduced activity of polyphenol oxidase catalyses auto-oxidation of phenolic compounds (Zhou et al., 2008). The fruit coated with CMC (2.0 $\left.\mathrm{g} \mathrm{L}^{-1}\right)$ exhibited significantly the highest level of total phenols may be argued that coatings provide a protecting barrier on the fruit surface there by minimizes the supply of oxygen responsible for enzymatic oxidation of phenolic compounds (Zheng and Quntick, 1997). Previously, the post-harvest application of $\mathrm{CMC}$ alone and in a combination with guar gum-based silver nanoparticles exhibited significantly the highest level of total phenols in 30 days and 120 days cold-stored 'Kinnow' mandarin fruit, respectively in contrast to other coating treatments and control (Ali et al., 2021; Shah et al., 2015). Silver (Ag) is a heavy metal and unsafe for human consumption and the environment. Likewise, 'Golden Drop' plum fruit coated with $\mathrm{CMC}$ and pectin based edible coatings showed significantly the highest level of total phenols for up to 8 days in contrast to other coating treatments and control (Panahirad and Naghshiband-Hassani, 2020). The fruit coated with CMC $\left(2.0 \mathrm{~g} \mathrm{~L}^{-1}\right)$ exhibited significantly the highest total antioxidant activity may be due to the reflection of higher levels of total phenols (Khaliq et al., 2015). Previously, the post-harvest application of CMC alone and in a combination with guar gumbased silver nanoparticles exhibited significantly the highest total antioxidant activity in 30 days and 120 days cold-stored 'Kinnow' mandarin fruit, respectively in contrast to all other coating treatments and control (Ali et al., 2021; Shah et al., 2015). However, Ag is a heavy metal and reckless for human health and the environment. Similarly, the fruit coated with CMC manifested significantly the highest total antioxidant activity for up to 16 days in cold-stored Indian blackberry (Syzygium cumini L.) fruit in contrast to other coating treatments and control (Gol et al., 2015). Retention of the highest flavonoids content in $\mathrm{CMC}\left(2.0 \mathrm{~g} \mathrm{~L}^{-1}\right)$ coated fruit may be ascribed to the reduced activity of manonyl transferase responsible for the biosynthesis of flavonoids (Caro et al., 2004). Previously, the 'Golden Drop' plum fruit coated with $\mathrm{CMC}$ and pectin-based edible coatings significantly exhibited the highest level of flavonoids for up to 8 days in contrast to all other coating treatments and control. Likewise, the postharvest coating with chitosan significantly maintained the highest level of flavonoids in 9 days of cold-stored strawberry fruit in contrast to other coating treatments and control 
(Petriccione et al., 2015). Higher protein content in the fruit coated with $\mathrm{CMC}\left(2.0 \mathrm{~g} \mathrm{~L}^{-1}\right)$ may be due to restriction in ethylene-induced electrolyte leakage facilitates the accumulation of higher protein content (Jiang et al., 2002). Though the exact mechanism of how coatings influence the dynamics of protein content during cold storage is not fully understood therefore requires further investigations. Recently, cucumber fruit coated with chitosan $\left(250 \mathrm{~g} \mathrm{~L}^{-1}\right)$ recorded significantly higher protein content for up to 28 days at ambient storage conditions in contrast to other coating treatments and control (Elizabeth and Mimololuwa, 2020). The fruit coated with CMC $\left(2.0 \mathrm{~g} \mathrm{~L}^{-1}\right)$ exhibited significantly highest total free amino acids content in the juice may be due to its negative reflection on protein content as the level of amino acids increases due to degradation in protein with an extension in the cold storage period (Tulio et al., 2002). However, there is no clear evidence as to how the coatings influence the dynamics of amino acids during storage therefore demands subsequent investigations. Coatings retards the starch-sugars conversion process and consequently delays a rise in the sugars level (Haider et al., 2017). CMC (2.0 g $\mathrm{L}^{-1}$ ) exhibited significantly highest sugars level may be due to CMC delayed the starch-sugar conversion process and subsequently reduced the rise in the levels of sugars in coldstored 'Kinnow' mandarin fruit. Likewise, the post-harvest coating with $\mathrm{CMC}$ alone or $\mathrm{CMC}$ with silver nanoparticles has suppressed an increase in levels of sugars in 30 days and 120 days cold-stored 'Kinnow' mandarin fruit in contrast to other coating treatments and control (Ali et al., 2020; Shah et al., 2015). However, CMC containing silver nanoparticles coating cannot be used in fresh horticultural produce as silver is a heavy metal and unfit for human consumption and detrimental to the environment.

\section{Materials and methods}

\section{Fruit}

'Kinnow' mandarin (Citrus nobilis Lour x C. deliciosa Tenora) fruit of uniform size (250-300 g) were harvested at harvest maturity (sugar/acid ratio 12:1) from the uniform and healthy tress selected and maintained in an orchard located at Regional Fruit Research Station, Abohar $\left(30^{\circ} 55^{\prime} \mathrm{N}, 54^{\circ} 30^{\prime} \mathrm{E}\right)$. 'Kinnow' mandarin fruit used in the experiments were harvested from the same block during the years of 2017-18 and 2018-19 from the fifteen years old healthy trees grafted on rough lemon rootstock (Citrus jambhiri L.). Following sorting and grading operations, the fruit were washed with $0.01 \%$ chlorinated water (sodium hypochlorite $4 \% @ 2.5 \mathrm{ml} \mathrm{L}^{-1}$ ) and allowed to dry overnight at room temperature (25 ㄷ).

\section{Treatments}

The fruit were coated with different consecrations of coating compounds including $\mathrm{CMC}\left(1.0,1.5\right.$ and $2.0 \mathrm{~g} \mathrm{~L}^{-1}$ respectively), chitosan $\left(0.5,1.0\right.$ and $1.5 \mathrm{~g} \mathrm{~L}^{-1}$ respectively), beeswax $(5,10$ and $15 \mathrm{~g} \mathrm{~L}^{-1}$ respectively) and control (uncoated fruit) at room temperature $\left(24 \pm 1^{\circ} \mathrm{C}\right.$ and $\left.65 \pm 5 \% \mathrm{RH}\right)$ following procedures previously detailed by Baswal et al. (2020a). Following coating treatments, the fruit were allowed to dry at room temperature and packed in corrugated fiber boxes (CFB) of two kg capacity and kept in cold storage $\left(5-7^{\circ} \mathrm{C}\right.$ and $\left.90-95 \% \mathrm{RH}\right)$ for $30,45,60$ and 75 days. The juice was extracted from 12 fruit per replication using a juice extractor and the pooled juice from each replication was used to estimate the levels of total phenols, total antioxidant activity, flavonoids, protein, total free amino acids and total and reducing sugars following 30, 45,60 and 75 days of cold storage. For zero-day data, freshly harvested fruit were also analyzed.

\section{Experimental design and number of replications}

Both the experiments were laid out by following two factors (coating treatments and cold storage periods) factorial completely randomized design with three replicates in 2017-18 and 2018-19. Twelve fruit were included in each replication during both years.

\section{Observations recorded}

\section{Determination of total phenols, total antioxidant activity and flavonoids}

The levels of total phenols were estimated by preceding the Folin-Ciocalteu colorimetric method (Mayers et al., 2003) with minor changes described previously by Baswal et al. (2020b, 2021) and the concentrations were calculated as mg gallic acid equivalents (GAE) $100 \mathrm{ml}^{-1}$ juice. Total antioxidant activity was determined by preceding procedures detailed earlier by BrandWilliams et al. (1995) with minor changes earlier detailed by Baswal et al. (2020b, 2021) and expressed in percentage. The flavonoids were determined as per methods earlier described by Chang et al. (2002) with minor changes (Baswal et al., 2021) and estimated as mg quercetin $100 \mathrm{ml}^{-1}$ juice.

\section{Determination of protein, total free amino acids, total and reducing sugars}

Protein content was estimated by following the standard procedure previously detailed by Lowery et al. (1951) with minor changes earlier outlined by Baswal et al. (2021) and expressed as mg $100 \mathrm{ml}^{-1}$ juice. To determine the levels of total free amino acids, the previously explained methods by Yemm and Cocking (1954) recently specified by Baswal et al. (2021) were used. Total free amino acids were expressed as mg 100 $\mathrm{ml}^{-1}$ juice. From the fresh 'Kinnow' juice total and reducing sugars were estimated by preceding the procedures earlier explained by Hortwitz (1960) with minor changes recently enumerated by Baswal et al. (2021) and calculated as a percentage.

\section{Statistical analysis}

The data were analyzed by two-way ANOVA using procedures of the Statistical Analysis System 9.3 (S.A.S. Institute Inc., Cary, NC, USA). The effect of different coating treatments and cold storage periods and their interaction were assessed within ANOVA. The treatment means were compared using the least significance difference (LSD) values at a level of significance of $P \leq 0.05$. The data of both years (2016-17 and 2017-18) were pooled due to homogeneity of variance over two years.

\section{Conclusion}

The post-harvest coating application of CMC $\left(2.0 \mathrm{~g} \mathrm{~L}^{-1}\right)$ maintained significantly the highest levels of total phenols, total antioxidant activity, flavonoids, protein and total free amino acids as compared to control and all other treatments 
for up to 60 days cold-storage of 'Kinnow' mandarin fruit. The postharvest application of CMC did not result in any harmful effects on the fruit.

\section{Acknowledgements}

Dr A K Baswal gratefully acknowledges University Grants Commission, New Delhi, India for financial support as a Junior Research Fellowship.

\section{References}

Ali S, Anjum MK, Ejaz S, Hussaain S, Ercisli S, Saleem MS, Sardar H (2021) Carboxymethyl cellulose coating delays chilling injury development and maintains eating quality of 'Kinnow' mandarin fruits during low temperature storage. Int J Biol Macromol. 168:77-85.

AOAC (2005) Official methods of analysis, $18^{\text {th }}$ edn. Association of Official Analytical Chemists, Washington DC.

Arnon H, Granit R, Porat R, Poverenov E (2015) Development of polysaccharides-based edible coatings for citrus fruits: $A$ layer-by-layer approach. Food Chem.166:465-472.

Baswal AK, Dhaliwal HS, Singh Z, Mahajan BVC, Kalia A, Gill KS (2020a) Influence of carboxymethylcellulose, chitosan and beeswax coatings on cold storage life and quality of 'Kinnow' mandarin fruit. Sci Hortic. 260:108887.

Baswal AK, Dhaliwal HS, Singh Z, Mahajan BVC (2020b) Influence of types of modified atmospheric packaging (MAP) film on cold-storage and fruit quality of 'Kinnow' mandarin (Citrus nobilis Lour $\times$ C. deliciosa Tenora). Int J Fruit Sci.https://doi.org/10.1080/15538362.2020.1818163

Baswal AK, Dhaliwal HS, Singh Z, Mahajan BVC (2021) Postharvest application of methyl jasmnate, 1methylcyclopropene and salicylic acid elevates healthpromoting compounds in cold-stored 'Kinnow' mandarin (Citrus nobilis Lour x C. deliciosa Tenora) fruit. Int J Fruit Sci.https://doi.org/10.1080/15538362.2020.1860865.

Caro AD, Piga A, Vacca V, Agabbio M (2004) Changes of flavonoids, vitamin $C$ and antioxidant capacity in minimally processed citrus segments and juices during storage. Food Chem. 84:99-105.

Chang CC, Yang MH, Wen HM, Chern JC (2002) Estimation of total flavonoid content in propolis by two complementary colorimetric methods. J Food Drug Anal. 10:178-182.

Chen C, Zheng J, Wan C, Chen M, Chen J (2016) Effect of carboxymethyl cellulose coating enriched with clove oil on postharvest quality of 'Xinyu' mandarin oranges. Fruits 71:319-327.

Dhall RK (2013) Advances in edible coatings for fresh fruits and vegetables: A review. Crit Rev Food Sci Nutr. 53:435-450.

Dong H, Cheng L, Tan J, Zheng K, Jiang Y (2004) Effect of chitosan coating on quality and shelf-life of peeled litchi fruit. J Food Eng. 64:355-358.

Elizabeth AA, Mimololuwa GP (2020) Effects of chitosan and aloe vera gel coatings on the preservation characteristics of cucumber samples. Adv J Grad Res. 8:82-90.

Eshetu A, Ibrahim AM, Forsido SF, Kuyu CG (2019) Effects of beeswax and chitosan treatments on quality and shelf life of selected mango (Mangifera indica L.) cultivars. Heliyon. 5, e01116.
Ghasemnezhad M, Shiri MA, Sanavi M (2010) Effect of chitosan coatings on some quality indices of apricot (Prunus armeniaca L.) during cold storage. Casp J Environ Sci.8:25-33.

Gol NB, Vyas PB, Rao TVR (2015) Evaluation of polysaccharidebased edible coatings for their ability to preserve the postharvest quality of Indian Blackberry (Syzygium cumini L.). Int J Fruit Sci.15:198-222.

Habibi F, Ramezanian A (2017) Vacuum infiltration of putrescine enhances bioactive compounds and maintains quality of blood orange during cold storage. Food Chem. 227:1-8.

Hong K, Xie J, Zhang L, Sun D, Gong D (2012) Effects of chitosan coating on postharvest life and quality of guava (Psidium guajava L.) fruit during cold storage. Sci Hortic. 144:172-178.

Hosseini SF, Amraie M, Salehi M, Mohseni M., Aloui H (2018) Effect of chitosan-based coatings enriched with savory and/or tarragon essential oils on postharvest maintenance of kumquat (Fortunella sp.) fruit. Food Sci Nutr.https://doi.org/10.1002/fsn3.835

Jo Y, Nam HA, Ramakrishnan SR, Baek ME, Lim S, Bin, Kwon JH (2018) Postharvest irradiation as a quarantine treatment and its effects on the physicochemical and sensory qualities of Korean citrus fruits. Sci Hortic. 236:265-271. https://doi.org/10.1016/j.scienta.2017.12.029

Khaliq G, Mohamed MTM, Ali A, Ding P, Ghazali HM (2015) Effect of gum arabic coating combined with calcium chloride on physico-chemical and qualitative properties of mango (Mangifera indica L.) fruit during low temperature storage. Sci Hortic. 190:187-194.

Khorram F, Ramezanian A, Hosseini SMH (2017) Effect of different edible coatings on postharvest quality of 'Kinnow' mandarin. J Food Meas Charact. 11:1827-1833.

Kumar P, Sethia S, Sharma RR, Srivastav M, Varghese E (2017) Effect of chitosan coating on postharvest life and quality of plum during storage at low temperature. Sci Hortic. 226:104109.

Nasrin TAA, Rahman MA, Arfin MS, Islam MN, Ullah MA (2020) Effect of novel coconut oil and beeswax edible coating on postharvest quality of lemon at ambient storage. J Agric Food Res. 2:100019.

Panahirad S, Naghshiband-Hassani R (2020) Shelf life quality of plum fruits (Prunus domestica L.) improves with carboxymethylcellulose-based edible coatings. HortScience 54:505-510.

Panche AN, Diwan AD, Chandra, SR (2016) Flavonoids: an overview. J Nat Sci. 5:1-15.

Perez-Gago MB, Rojas C, del Rio MA (2002) Effect of lipid type and amount of edible hydroxypropyl methylcellulose-lipid composite coatings used to protect postharvest quality of mandarins cv. Fortune. J Food Sci. 67:2903-2910.

Petriccione $M$, Mastrobuoni F, Pasquariello MS, Zampella, Nobis E, Capriolo G, Scortichini M (2015) Effect of chitosan coating on the postharvest quality and antioxidant enzyme system response of strawberry fruit during cold storage. Foods 4:501-523.

Rapisarda P, Bianco ML, Pannuzzo P, Timpanaro N (2008) Effect of cold storage on vitamin $\mathrm{C}$, phenolics and antioxidant activity of five orange genotypes [Citrus sinensis (L.) Osbeck]. Postharvest Biol Technol. 49:348-354. 
Reddy CVK, Sreeramulu D, Raghunath M (2010) Antioxidant activity of fresh and dry fruits commonly consumed in India. Food Res Int. 43:285-288.

Ryall AL, Pentzer WT (1982) Handling, transportation and storage of fruits and vegetables. AVI Pub. Co. Inc, Westport.

Saberi B, Golding JB, Marques JR, Pristijono $P$, Chockchaisawasdee S, Scarlett CJ, Stathopoulos CE (2018) Application of biocomposite edible coatings based on pea starch and guar gum on quality, storability and shelf life of "Valencia" oranges. Postharvest Biol Technol. 137:9-20.

Sdiri S, Bermejo A, Aleza P, Navarro P, Salvador A (2012) Phenolic composition, organic acids, sugars, vitamin $C$ and antioxidant activity in the juice of two new triploid lateseason mandarins. Food Res Int. 49:462-468.

Shah SWA, Jahangir M, Qaisar M, Khan SA, Mahmood T, Saeed M, Farid A, Liaquat M (2015) Storage stability of 'Kinnow' fruit (Citrus reticulata) as affected by CMC and guar gumbased silver nanoparticle coatings. Molecules 20:2264522661.

Shahid MA, Abbasi NA (2011) Effect of beewax coating on physiological changes in fruits of sweet orange cv. "Blood Red". Sarhad JAgric. 27:386-394.

Shi S, Wang W, Liu L, Wu S, Wei Y, Li W (2013) Effect of chitosan/nano-silica coating on the physico-chemical characteristics of longan fruit under ambient temperature. J Food Eng.118:125-131.

Tesfay, S.Z., Magwazaa, L.S. 2017. Evaluating the efficacy of moringa leaf extract, chitosan and carboxymethylcellulose as edible coatings for enhancing quality and extending postharvest life of avocado (Persea americana Mill.) fruit. Food Packag. Shelf Life. 11:40-48.
Togrul H, Arslan N (2004) Extending shelf-life of peach and pear by using CMC from sugar beet pulp cellulose as a hydrophilic polymer in emulsions. Food Hydrocoll. 18:215226.

Tulio AZ, Ose JR, Chanchin K, Ueda Y (2002) Effects of temperatures on postharvest quality jute leaves (Corchorus olitorius L.). Postharvest Biol. Technol. 26:329- 338.

Wang SY, Gao H (2013) Effect of chitosan-based edible coating on antioxidants, antioxidant enzyme system, and postharvest fruit quality of strawberries (Fragaria $\mathrm{x}$ ananassa Duch.). LWT-Food Sci Technol. 52:71-79.

Ye XQ, Chen JC, Liu DH, Jiang P, Shi J, Xue S, Wu D, Xu JG, Kakuda $Y(2011)$ Identification of bioactive composition and antioxidant activity in young mandarin fruits. Food Chem.124:1561-1566. https://doi.org/10.1016/j.foodchem.2010.08.013

Zhang DL, Quantick PC (1997) Effects of chitosan coating on enzymatic browning and decay during postharvest storage of litchi (Litchi chinensis Sonn.) fruit. Postharvest Biol Technol. 12:195-202.

Zhou R, Mo Y, Li Y, Zhao Y, Zhang G, Hu Y (2008) Quality and internal characteristics of Huanghua pears (Pyrus pyrifolia Nakai. cv. Huanghua) treated with different kinds of coatings during storage. Postharvest Biol Technol. 49:171-179. 